\title{
Survival, proximate composition, and proteolytic activity of Artemia salina bioencapsulated with different algal monocultures
}

\author{
Larysa Cheban, Oleksii Khudyi, Maja Prusińska, Arkadiusz Duda, Lidiia Khuda, \\ Grzegorz Wiszniewski, Olha Kushniryk, Andrzej Kapusta
}

Received - 16 February 2020/Accepted - 21 November 2020. Published online: 31 December 2020; $\odot$ Inland Fisheries Institute in Olsztyn, Poland Citation: Cheban L., Khudyi O., Prusińska M., Duda A., Khuda L., Wiszniewski G., Kushniryk O., Kapusta A. 2020 - Survival, proximate composition, and proteolytic activity of Artemia salina bioencapsulated with different algal monocultures - Fish. Aquat. Life 28: 205-215

\begin{abstract}
This study focused on testing Artemia sp. zooplankton saturation with freshwater microalgae biomass and then using this method to correct the nutritional composition of Artemia. Accordingly, the influence of three species of microalgal monocultures was analyzed (2 freshwater - Desmodesmus armatus (Chod.) Hegew. and Chlorella vulgaris Veijerinck; one halophilous - Dunaliella viridis Teodor.). The algal monocultures were applied once in a quantity of $2-3 \times 10^{6}$ cells $\times 1^{-1}$ for each 200,000 Artemia individuals hatched. The control group Artemia did not receive algae. The enrichment process lasted $24 \mathrm{~h}$, and control measurements were performed every $6 \mathrm{~h}$. The survival of Artemia nauplii, their proteolytic activity, and the content of proteins, lipids, and carotenoids were analyzed. The choice of algae species for Artemia enrichment was guided by the size of the algal cells and their biochemical composition. Selected algae contained about 50\% protein, 20\% lipid, and $12 \mathrm{mg}$ of carotenoids per $g$ of dry weight. Using algae to saturate the Artemia nauplii permitted reducing their mortality during the $24 \mathrm{~h}$ enrichment regime. The introduction of $C$. vulgaris biomass halved this value. The use of algae also increased the
\end{abstract}

\footnotetext{
L. Cheban [ $\left.\Xi^{\circ}\right]$, O. Khudyi, L. Khuda, O. Kushniryk

Department of Biochemistry and Biotechnology, Yuriy Fedkovych Chernivtsi National University,

Kotsubinsky Street 2, Chernivtsi, 58012, Ukraine

e-mail: l.cheban@chnu.edu.ua

M. Prusińska, A. Duda, G. Wiszniewski, A. Kapusta Department of Ichthyology, Hydrobiology and Aquatic Ecology, Stanisław Sakowicz Inland Fisheries Institute, ul. Oczapowskiego 10, 10-719, Olsztyn-Kortowo, Poland
}

proteolytic activity in Artemia nauplii and the content of proteins, lipids, and carotenoids in their biomass. The best results of the bioencapsulation of Artemia nauplii with algae was with the $C$. vulgaris biomass.

Keywords: Artemia, green algae, bioencapsulation, proteolytic activity, proteins, lipids, carotenoids

\section{Introduction}

One important element of aquaculture is obtaining high quality fish stocks. This cannot be achieved without using nutrient-balanced feeds. Live feeds significantly increase the survival rates of early developmental fish stages (Watanabe et al. 1983, Aruho et al. 2020). The organisms cultivated are usually those that are part of the natural food base of fishes. These feed items have high nutritional value and high contents of irreplaceable nutrients such as essential amino acids, fatty acids, enzymes, vitamins, and minerals (Conceição et al. 2010).

Artemia nauplii are easy to produce, so they are often the first feed offered to larval fish as they make to shift to exogenous food (Conceição et al. 2010, Hamre et al. 2013). However, Artemia are an incomplete source of food as their composition lacks some 
basic elements, for example, polyunsaturated fatty acids that are often required for the successful development of larval fishes (Sorgeloos et al. 2001, Kolman et al. 2018). The level of essential compounds in live feed can be increased through bioencapsulation with various substances, including amino acids, proteins, polyunsaturated fatty acids, carotenoids, and even probiotics (Monroig et al. 2007, Viciano et al. 2015). Compounds incorporated into the diet of Artemia can be in commercial liquids or the organic matter of feed organisms (bacteria, yeast, or microalgae) (Harel et al. 2002, Prusińska et al. 2015). Using highly purified commercial supplements of essential compounds for bioencapsulation significantly increases the final cost of aquaculture products. The solution to this problem is to use the biomass of the producers, in particular microalgae, for both feeding zooplankton and the joint cultivation of these two groups of organisms (Cheban et al. 2018, Bernaerts et al. 2019). The successful use of algae as feed for crustaceans and plankton-feeding fishes, as well as for all stages of bivalve mollusks is well known (Ovie and Egborge 2002, Becker 2007, Van Der Meeren et al. 2007).

The key characteristics when choosing algae as feed substrates are their size, biomass growth rate, resistance to environmental fluctuations, nutritional value, and the absence of toxic compounds in their biomass (Villarruel-López et al. 2017, Cheban et al. 2018). Algal nutritional value is linked significantly to the characteristics of species and can be adjusted depending on growing conditions (Hu et al. 2008, González López et al. 2010). Thus, protein content in algal biomass fluctuates from 45 to $70 \%$, while lipid content ranges from 10 to 30\%, and changes of fatty acid profiles and the quantities of some fatty and amino acids are also observed (Salama et al. 2013, Samek et al. 2013). Therefore, carefully selected microalgal monocultures or mixtures are proposed as excellent feed substrate for fish introduced into the diet by direct feeding or indirectly by their bioencapsulation into feed zooplankton (Becker 2007, Duong et al. 2015). The joint cultivation of Artemia nauplii and their feed organisms, in particular algae, also solves the problem of nauplii death when they are kept in automatic feeders. In addition to increasing survival rates, this also helps to reduce nauplii starvation and preserve or even increase their nutritional value. To facilitate implementing this idea, a study was devised to assess the impact of three microalgae monocultures, namely Desmodesmus armatus (Chod.) Hegew., Chlorella vulgaris Veijerinck, and Dunaliella viridis Teodor., on the survival rate and nutritional composition of Artemia sp. nauplii.

\section{Materials and Methods}

\section{Conditions for algal cultivation}

The research was conducted using pure cultures of the green algae Desmodesmus armatus, Chlorella vulgaris, and Dunaliella viridis obtained from the collection of the M.G. Kholodny Institute of Botany of the National Academy of Sciences of Ukraine (IBASH-A). Currently these cultures are maintained in the collection of the Institute of Biology, Chemistry, and Bioresourses, Yuriy Fedkovych Chernivtsi National University. Wastewater from a recirculating aquaculture system (RAS) was used as the culture medium for $D$. armatus and $C$. vulgaris algae (Cheban et al. 2015, Khudyi et al. 2016), while a $\mathrm{NaCl}$ in the amount of $1 \mathrm{M}$ was added to the $D$. viridis cultivation. All the manipulations of the cultures were conducted under the sterile conditions of a laminar flow hood. Cultivation was conducted in a climatic room with $16 \mathrm{~h}$ of illumination with fluorescent lamps at 2500-4000 lux and a temperature of $28 \pm$ $2^{\circ} \mathrm{C}$. Microalgae cultivation lasted for 21 days until the culture reached a stationary growth phase. Then the number of cells in the algae suspension was counted with microscopy and a Goryaev chamber.

\section{Artemia cyst incubation and nauplii bioencapsulation}

Artemia sp. cysts (Sepia Art Artemia, Ocean Nutrition, Belgium) were incubated in illuminated, 
oxygenated 81 Weiss flasks for $24 \mathrm{~h}$ at a temperature of $28^{\circ} \mathrm{C}$. The salinity of the incubation medium for cysts was provided by adding of $\mathrm{NaCl}$ at a dose of 15 $\mathrm{g} \times \mathrm{l}^{-1}$. The release of nauplii under these conditions occurs within $24 \mathrm{~h}$ of placing the cysts into the incubation medium.

After sorting out cyst capsules and unhatched cysts, freshly hatched Artemia larvae at a density of 200,000 individuals were transferred to enrichment flasks filled with salt water. Biomasses of freshwater microalgae $D$. armatus and $C$. vulgaris and saltwater algae $D$. viridis was used for saturation, which was applied once in a quantity of 2-3 $310^{6}$ cells $\times 1^{-1}$. Artemia from the control group did not receive algal biomass. Four experimental groups were formed: group I - Artemia nauplii without feeding (control group); group II - Artemia nauplii $+D$. armatus; group III - Artemia nauplii + C. vulgaris; group IV Artemia nauplii $+D$. viridis.

Freshwater algae species are characterized by small cells, and they lack rigid cell wall outgrowths (Table 1). For comparison, saltwater algae D. viridis was used for zooplankton saturation, and it was also analyzed. This microalgal species does not have a polysaccharide cell wall, which is replaced by a thin elastic cell membrane. This fact probably suggests using given algal species as zooplankton feed. Algal size is also important; it should not exceed the size of the Artemia nauplii filter apparatus. The smallest among the proposed algae are the cells of $C$. vulgaris, which ranges from 5 to $10 \mu \mathrm{m}$. Due to the small cell size of $10-20 \mu \mathrm{m}$ in length and 3.5-8 $\mu \mathrm{m}$ in width, $D$. armatus can also be used as a feed substrate for zooplankton bioencapsulation and for feeding fish fry.
Every $6 \mathrm{~h}$ from the beginning of the experiment, the total number and the number of dead crustaceans in the experimental and control groups were counted. For this purpose $0.2 \mathrm{ml}$ of culture medium was analyzed in Bogorov counting chambers after Lugol's solution had been added. Then the total number of Artemia was counted in the samples. The mortality rate was estimated by the Cumulative Mortality Index (CMI), which was calculated as the ratio of the sum of dead individuals at that and in previous hours to the total number of individuals in the sample at that and in previous hours:

$$
C M I_{i}=\frac{\sum_{0}^{24} n_{i}}{\sum_{0}^{24} N_{i}} \times 100
$$

$n$ - the number of dead individuals per i h;

$N$ - total number of individuals per i h;

$i$ - duration of feeding $(0,6,12,24 \mathrm{~h})$.

\section{Biochemical analysis of algae and Artemia nauplii}

Algal and Artemia nauplii biomass was concentrated by centrifugation at $5000 \mathrm{rpm}$ for 15 minutes on a Heraeus Biofuge ${ }^{\circledR}$ Stratos ${ }^{\circledR}$. The hydrated biomass was homogenized by adding $0.1 \mathrm{M}$ phosphate buffer with a $\mathrm{pH}$ of 7.4. Ultrasonic Cleaner was used to destroy the biomass. The total protein content was determined with Lowry's method (Lowry et al. 1951). The determination of total lipids extracted with Folch's method (Folch et al. 1957) was conducted

Table 1

Characteristics of algal cells (Hosseini Tafreshi and Shariati 2009, Nermin 2011, Safi et al. 2014)

\begin{tabular}{lllll}
\hline \hline & \multicolumn{2}{l}{ Alga characteristics } & & \\
\cline { 2 - 5 } Alga species & Size & Cell wall & Cell wall outgrowths & Salinity tolerance \\
\hline \hline D. armatus & Length: $10-20 \mu \mathrm{m}$ & Present & minor bulges & Freshwater species \\
& Width: $3.5-8 \mu \mathrm{m}$ & & & Freshwater species \\
C. vulgaris & Diameter: $6-8 \mu \mathrm{m}$ & Present & Absent & Saltwater species \\
D. viridis & Length: $5.1-17.0 \mu \mathrm{m}$ & Absent & Absent & \\
\hline \hline
\end{tabular}


with the acid hydrolysis of the samples followed by the reaction between decomposition products and a phospho-vanillin reagent (Knight et al. 1972). The carbohydrate content was determined with a color reaction and an anthrone reagent (Roe 1955).

The carotenoids and chlorophyll were extracted with absolute acetone and centrifuged at $3000 \mathrm{rpm}$ for 15 minutes. The spectra of pigments in the range of 450-690 nm were measured in the supernatant. The calculation of pigment concentration was performed according to conventional formulas (Tanaka 1978, Macías-Sánchez et al. 2008). The proteolytic activity was investigated with the modified Anson method (GOST 20264.2-88 1988). First, the nauplii were homogenized with universal buffer with $\mathrm{pH}$ of 4.8, 7.4, and 9.0. Casein was used as a substrate to determine neutral and alkaline proteases, and a hemoglobin solution was used as a substrate for acidic proteases. Enzyme activity was expressed in conventional units per mg protein, where 1 unit (U) corresponded to that amount of enzyme that catalyzes the conversion of 1 micromole of substrate in $1 \mathrm{~m}$. All calculations were performed on dry weights. To determine humidity and dry weights, previously weighed samples were dried at $60^{\circ} \mathrm{C}$ for $24 \mathrm{~h}$ to a constant mass (Harris et al. 2000).

\section{Statistical Analysis}

All data were presented as mean $\pm \mathrm{SE}$. The significance of differences in the results was evaluated with one-way ANOVA. Statistical analysis was computed using MS Excel and STATISTICA 6.0. Mean values were considered significantly different at $\mathrm{P} \leq 0.05$ according to Student's criterion.

\section{Results}

\section{Biochemical characteristics}

The lowest protein content among the species analyzed was observed in the biomass of $D$. viridis about $38 \%$ of the dry cell biomass (Table 2). The same culture was characterized by the highest level of lipid accumulation (37\%). Both species of freshwater algae (D. armatus and $C$. vulgaris) contained about $50 \%$ protein and about $25 \%$ lipid. All of the algal cultures analyzed had similar levels of carbohydrates. The content of the chlorophyll $\mathrm{a}$ and $\mathrm{b}$ pigments was similar in all three algae and was typical of green algae. Unexpectedly, the biomass of the freshwater algae $D$. armatus and $C$. vulgaris was characterized by fairly high contents of carotenoids at $10-15 \mathrm{mg} \times \mathrm{g}^{1}$ of dry weight.

\section{Mortality}

Enriching Artemia with algal cultures had a statistically significant impact on mortality in comparison with the experimental groups (Table 3). Initially, the lowest Artemia mortality was noted in the control group and group III (C. vulgaris). Artemia mortality increased in subsequent hours of enrichment.

Table 2

Biochemical characteristics of the algae used to enrich Artemia nauplii (mean \pm SE, $n=4)$.

\begin{tabular}{llll}
\hline \hline Indicators & D. viridis & D. armatus & C. vulgaris \\
\hline \hline Proteins (\%) & $37.5 \pm 1.87^{\mathrm{a}}$ & $46.8 \pm 2.15^{\mathrm{b}}$ & $49 \pm 0.76^{\mathrm{b}}$ \\
Lipids (\%) & $37.1 \pm 1.85^{\mathrm{a}}$ & $23.3 \pm 0.74^{\mathrm{b}}$ & $21.5 \pm 0.63^{\mathrm{b}}$ \\
Carbohydrates (\%) & $19.3 \pm 0.72$ & $18.2 \pm 0.69$ & $17.5 \pm 0.59$ \\
Chlorophyll $a\left(\mathrm{mg} \times \mathrm{g}^{-1}\right)$ & $11.5 \pm 0.57$ & $11.17 \pm 0.42$ & $11.7 \pm 0.58$ \\
Chlorophyll b $\left({\left.\mathrm{mg} \times \mathrm{g}^{-1}\right)}^{\text {Carotenoids }\left(\mathrm{mg} \times \mathrm{g}^{-1}\right)}\right.$ & $8.5 \pm 0.42$ & $7.07 \pm 0.29$ & $8.6 \pm 0.43$ \\
\hline \hline
\end{tabular}

Mean values in the same row with the same superscript were not significantly different $(\mathrm{P}>0.05)$ 
Table 3

Mortality (in \%) of Artemia sp. fed algae (mean \pm SE, $n=4$ ). Group I - Artemia nauplii without feeding (control group); group II Artemia nauplii with $D$. armatus; group III - Artemia nauplii with C. vulgaris; group IV - Artemia nauplii with D. viridis

\begin{tabular}{|c|c|c|c|c|c|}
\hline \multirow{2}{*}{$\begin{array}{l}\text { Experimental } \\
\text { group }\end{array}$} & \multicolumn{5}{|c|}{ Experiment hours } \\
\hline & 0 & 6 & 12 & 18 & 24 \\
\hline Group I & $7.8 \pm 0.15^{\mathrm{a}}$ & $17.6 \pm 0.36^{\mathrm{b}}$ & $28.9 \pm 0.63^{\mathrm{c}}$ & $32.7 \pm 0.89^{b}$ & $23.6 \pm 0.75^{b}$ \\
\hline Group II & $6.2 \pm 0.17^{b}$ & $17.9 \pm 0.45^{b}$ & $23.6 \pm 0.58^{b}$ & $36.3 \pm 0.81^{\mathrm{c}}$ & $33.1 \pm 0.68^{\mathrm{c}}$ \\
\hline Group III & $8.4 \pm 0.26^{\mathrm{a}}$ & $16.1 \pm 0.41^{\mathrm{a}}$ & $13.6 \pm 0.37^{\mathrm{a}}$ & $15.1 \pm 0.36^{\mathrm{a}}$ & $13.1 \pm 0.29^{\mathrm{a}}$ \\
\hline Group IV & $6.4 \pm 0.15^{\mathrm{b}}$ & $17.7 \pm 0.39^{b}$ & $23.1 \pm 0.49^{b}$ & $42.1 \pm 0.98^{c}$ & $57.3 \pm 1.34^{\mathrm{d}}$ \\
\hline
\end{tabular}

Mean values in the same column with the same superscript were not significantly different $(\mathrm{P}>0.05)$

Artemia enriched with $C$. vulgaris had the lowest mortality from $6 \mathrm{~h}$ of the experiment (Table 3, $\mathrm{P}<0.05)$. However, increased Artemia mortality in the groups enriched with $D$. armatus or $D$. viridis was noted after $18 \mathrm{~h}$ of the experiment.

\section{Proteolytic activity}

The activity of proteases, depending on their optimal $\mathrm{pH}$ value (acidic, neutral, alkaline), was also determined (Fig. 1). It should be noted that for all feed substrates used, the proteolytic activity in Artemia nauplii at the time of transition to exogenous feeding (from 9 to $12 \mathrm{~h}$ ) remained high enough for all isoforms compared with the control group. The exception was the option using $D$. viridis that correlated with high nauplii mortality under these saturation conditions. Of the freshwater algae, using $C$. vulgaris led to a sufficiently high background value of protease activity throughout all $24 \mathrm{~h}$ of enrichment. In almost all the saturation variants sufficiently high proteolytic activity in the homogenate biomass of Artemia nauplii occurred at $12 \mathrm{~h}$, when the lowest mortality of nauplii was also noted.

\section{Body composition}

At the beginning of the experiment, Artemia body composition did not differ between the control group and the groups enriched with algal cultures
(Fig. 2; $\mathrm{P}>0.05$ ). At this time, the protein content was about $50 \%$, the lipid content was about $17 \%$, and the carotenoid content was about $0.02 \%$. Algal enrichment affected these parameters significantly and differently. In the first $12 \mathrm{~h}$, the control group nauplii utilized about $30 \%$ of the protein present in their biomass and more than $50 \%$ of the available carotenoids, and this trend persisted for up to $24 \mathrm{~h}$ inclusive.

Saturation with $D$. armatus biomass permitted maintaining the amount of protein and lipid at values typical for nauplii at hatching. The introduction of $C$. vulgaris led to an increase in the amount of proteins in Artemia biomass compared to all other experimental groups (Fig. 2a). The level of proteins in the biomass of Artemia saturated with algae $D$. viridis was observed in the control values. However, under these conditions, the nauplii biomass was characterized by the highest lipid content of about $20 \%$. The lipid contents in Artemia enriched with D. armatus (group II) or C. vulgaris (group III) were significantly statistically higher $(\mathrm{P}<0.05)$ in comparison with group I (control) from $6 \mathrm{~h}$ (group III) and $12 \mathrm{~h}$ (group II) until the conclusion of the experiment (Fig. 2b). Saturating Artemia with any of the algae tested permitted increasing the level of carotenoids in the crustaceans throughout the enrichment period up to $24 \mathrm{~h}$ inclusive (Fig. 2c). This process was the most pronounced with $D$. armatus and $C$. vulgaris. However, the introduction of $D$. viridis produced a similar effect. Obviously, this was due to the fairly high initial carotenoid levels in all three alga species. 

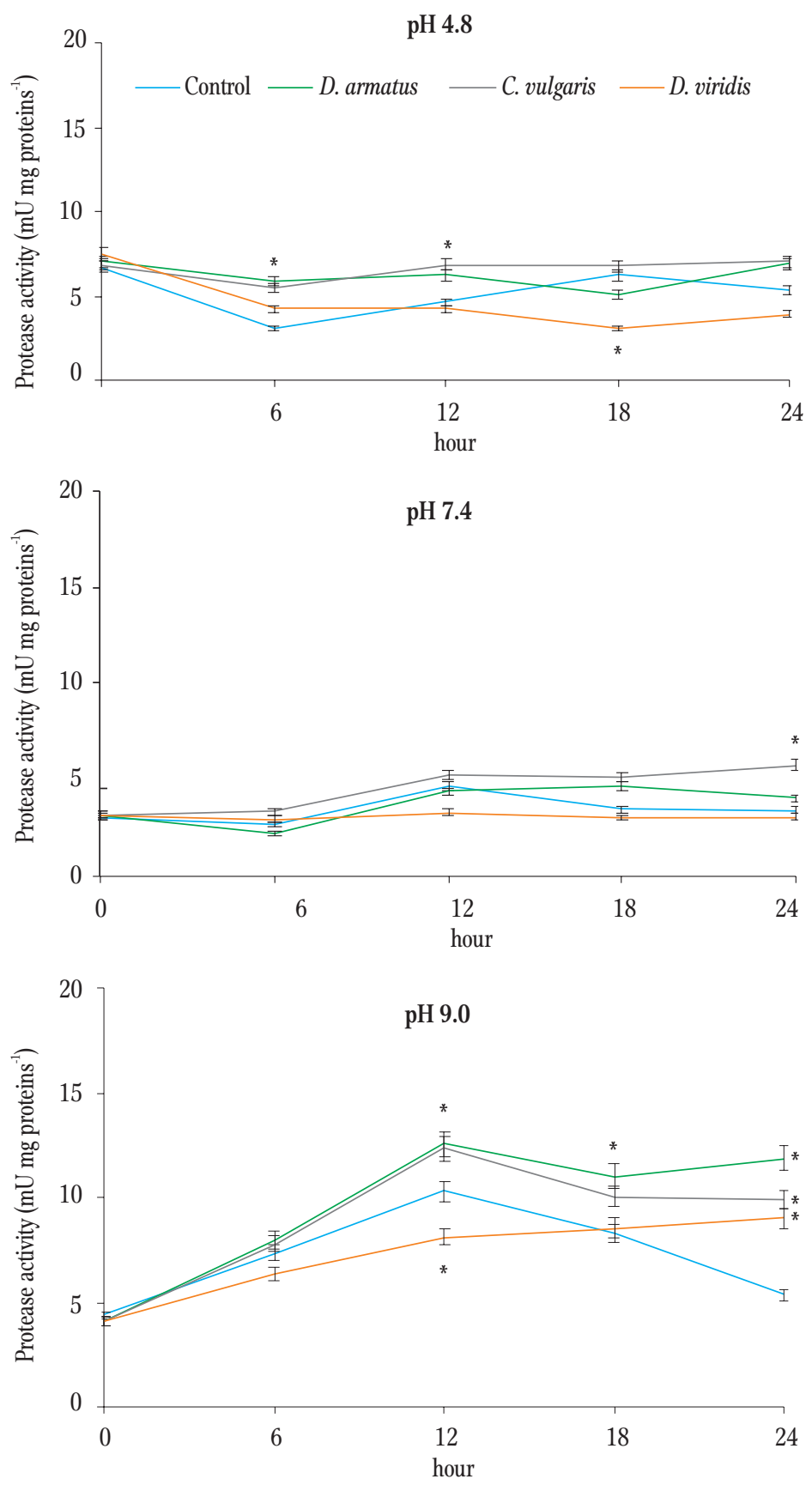

Figure 1. Proteolytic activity of Artemia sp. homogenate under bioencapsulation with algae biomass. ${ }^{*}$ mean values with star notation differed significantly from the control group $(\mathrm{P}<0.05)$.

\section{Discussion}

Algae used as a feed substrate should be small, i.e., 1-15 $\mu \mathrm{m}$ for zooplankton that filter feed and 10-100 $\mu \mathrm{m}$ for those with mouthparts capable of sucking (Brown 2002). These algae must also grow fast enough and contain enough nutrients. Saltwater algae such as Dunaliella viridis are appropriate for feeding saltwater zooplankton. Because of the peculiar structure of the cell surface, algae can change their shape, and they are easily digested and assimilated in the zooplankton alimentary tracts. $D$. viridis 


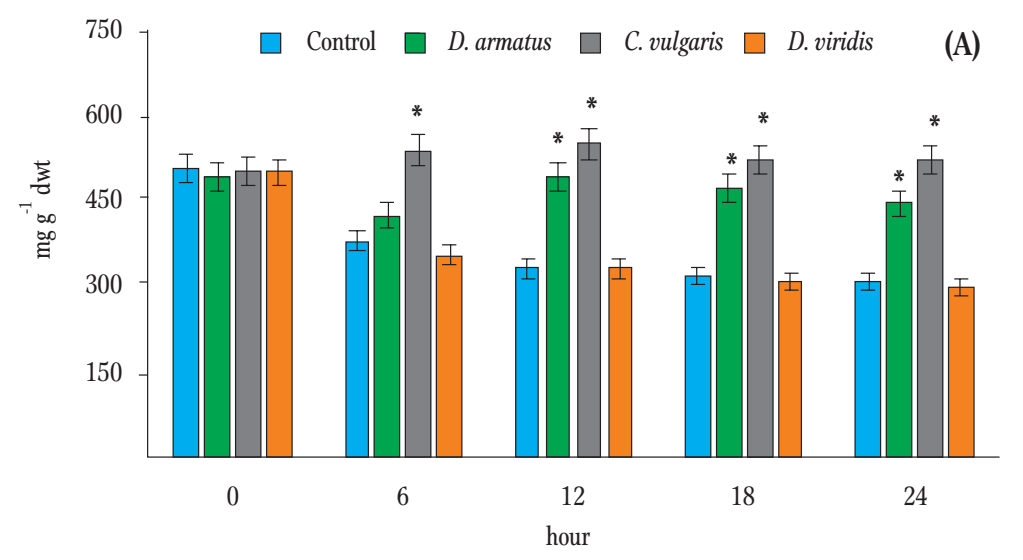

(B)
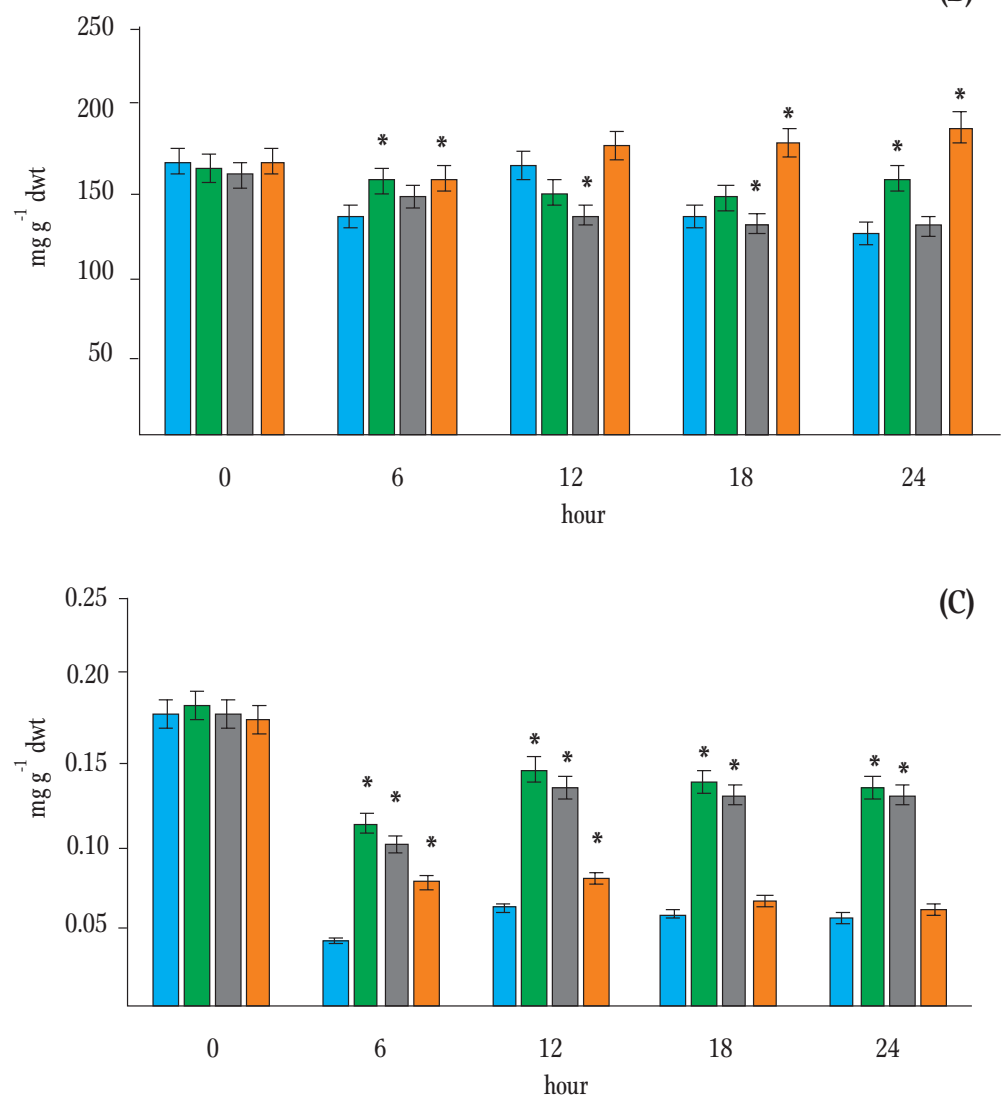

Figure 2. Content of proteins (A), lipids (B), and carotenoids (C) in Artemia sp. biomass following algal bioencapsulation. * mean values with star notation differed significantly from the control group $(\mathrm{P}<0.05)$.

is a halophilous species and can survive in environments with high salinity from $0.2 \%$ to $35 \%$. Additionally, it is able to grow at high light intensities, at elevated temperatures, and in wide ranges of $\mathrm{pH}$, and it is a natural source of $\beta$-carotene. In high salinity, this algae is able to accumulate large amount of lipids (Ben-Amotz et al. 2009, Hosseini Tafreshi and
Shariati 2009). In comparison with this species, freshwater algae biomasses were also used to saturate Artemia. Chlorella vulgaris is a freshwater unicellular green microalga, the cells of which have a spherical shape. One of the important characteristics of Chlorella is the protein content, which ranges from 42 to $58 \%$ of dry biomass depending on 
cultivation conditions; it is believed that the qualitative composition of these proteins is quite high. Chlorella is also rich in minerals and B-vitamins, especially vitamin B12 (Safi et al. 2014). D. armatus is also a freshwater green protococcal microalga. $D$. armatus is valuable forage object as it has a fairly high content of proteins, polyunsaturated fatty acids, vitamins, pigments, including carotenoids, and a balanced composition of amino acids (Nermin 2011). In terms of suitability for enriching Artemia, the algae selected meet the basic nutritional requirements. They have high protein and carotenoid contents and small cells.

In first few hours after hatching Artemia nauplii do not feed, but there is an active transport of substances through their integuments. For the first 6 to 9 h, Artemia feeds endogenously and utilizes nutrients from the yolk sac (Simon 2016). The transition to active exogenous feeding occurs after the first moult, when nauplii become metanauplii, which is when this crustacean begins to actively filter small food objects (algae, bacteria, protozoa). This is a rather critical stage in the Artemia life span. If a food substrate is not introduced in time, all of the hatched zooplankton will die. Guided by our previous results (Kushniryk et al. 2015, Cheban and Grynko 2017, Cheban et al. 2018), algae were introduced into the cultivation system immediately after the nauplii hatched.

Since the size of methanauplii usually does not exceed $50 \mu \mathrm{m}$, foraging objects that do not exceed a size of 3-8 $\mu \mathrm{m}$ are optimal for all stages of Artemia development (Makridis and Vadstein 1999). Between the two freshwater algae, the best results in reducing the mortality of Artemia nauplii throughout the experiment were achieved using $C$. vulgaris as compared to D. armatus. Obviously, these results depended on the cell size and physiological characteristics of the algae cultures. The size of $D$. armatus cells is from 10 to $20 \mu \mathrm{m}$ in length and 3.5 to $8 \mu \mathrm{m}$ in width, and there are no outgrowths on their cells. However, in addition to single cells, D. armatus is able to form conglomerates of 2-4 cells, which prevents their capture by Artemia (Nermin 2011).
The high mortality of Artemia nauplii during enrichment with $D$. viridis demands discussion. Algae of the genus Dunaliella are part of the natural food base of Artemia, and because they lack solid cell walls they are easily digested in the zooplankton intestinal tract. Nevertheless, Dunaliella remains virtually inaccessible for crustacean nauplii as it has large cell sizes from 5.1 to $17.0 \mu \mathrm{m}$ in length and from 3.0 to $15.2 \mu \mathrm{m}$ in width (Brown 2002). Thus, among all algae used, the saturation of Artemia nauplii with freshwater biomass of $C$. vulgaris reduced their mortality by almost half. This trend persisted for the $24 \mathrm{~h}$ during which the Artemia were kept in the feeders. Digestion in fish occurs mainly by hydrolytic enzymes of consumed live feed during the transition to exogenous feeding (Kolkovski 2001). Proteolytic enzymes of feed organisms are used to activate zymogens of digestive enzymes in fish larvae. The use of algal biomass to saturate Artemia significantly affected its enzymatic activity. In the present study it was found that the introduction of green algae C. vulgaris and $D$. armatus into the zooplankton diet stimulated an increase in the protease activity of all the enzyme isoforms in the food organisms. Sufficiently high indicators of protease activity when feeding Artemia nauplii with freshwater algae biomass permitted asserting the efficiency of zooplankton saturation with the biomasses of these algae.

One of the problems with the long-term storage of nauplii is they can lose their nutritional value. Artemia nauplii can contain from 50 to $65 \%$ protein, and storing Artemia for more than $12 \mathrm{~h}$ without feeding can lead to them using proteins, lipids, and carotenoids, which will significantly affect their value as feed. This should be avoided since the use of poor feed does not facilitate obtaining viable, reared fish larvae at an early stage or increasing their growth rates. Using the freshwater algae $C$. vulgaris and $D$. armatus avoided wasting valuable metabolites. Both algae contain sufficiently high contents of proteins in their own biomass, which helped to fully compensate for the crustaceans' protein requirements during their transition to exogenous feeding. The high lipid content in the original biomass of $D$. viridis explained the rather high lipid content in the Artemia nauplii 
biomass during the $24 \mathrm{~h}$ of enrichment with this algae. However, not only is the amount of lipids important, but the amount and ratio of fatty acids in the feed is also significant (Brett et al. 2006).

A positive result of the scheme applied to saturate nauplii with freshwater algae was the fairly high content of carotenoids. Crustaceans cannot synthesize these in their own bodies, so they must be consumed with feed organisms capable of carotenogenesis (algae, yeast, etc.) (Guedes et al. 2011). The sufficiently high content of carotenoids in the biomass of the freshwater algae $C$. vulgaris and $D$. armatus permitted maintaining a sufficiently high content in the biomass of nauplii throughout the saturation period. These values were significantly higher than values of both the control group of Artemia and the group saturated with D. viridis. It was obvious that the Artemia digestive tract digested and assimilated Chlorella biomass easily. In fact, the size and shape of Chlorella cells were optimal for Artemia to capture. Therefore, the possibility of feeding Artemia sp. with freshwater algae biomass was demonstrated and confirmed by the results of determining the survival of nauplii and their proteolytic activity. The most effective scheme was to saturate Artemia nauplii with the biomass of the freshwater algae $C$. vulgaris. The Artemia sp. individuals obtained can be used as a starting live feed for commercially important fish species.

\section{Conclusions}

1. The possibility and conditions of Artemia sp. saturation with freshwater algae $C$. vulgaris and $D$. armatus biomass were demonstrated by introducing 200,000 individuals of Artemia sp. nauplii into flasks for saturation with the simultaneous, one-time introduction of algae monoculture suspensions at rates of $2-3 \times 10^{6}$ cells $\times \mathrm{l}^{-1}$ and exposure for $24 \mathrm{~h}$ at a temperature of $24^{\circ} \mathrm{C}$.

2. According to the survival rates of the nauplii and their high proteolytic activity, the Artemia spp. saturation scheme with freshwater algae $C$. vulgaris biomass was determined to be optimal.
3. The high content of total protein and carotenoids in Artemia nauplii biomass obtained as a result of saturation with freshwater algae $C$. vulgaris permitted designating them for use as starting live feed for commercially important fish species.

Acknowledgments. This study was supported financially by the Stanisław Sakowicz Inland Fisheries Institute (statutory research topic no. S-009).

Author contributions. L.C. and O.Kh. designed the research; M.P., A.D., L.K., G.W. and O.Ku. performed the research; L.C., O.Kh. and L.K. analyzed the data; L.C., O.Kh., L.K., O.Ku. and A.K. wrote the paper.

ORCID ID

Larysa Cheban (iD https://orcid.org/0000-0003-1454-0158

Oleksii Khudyi（iD https://orcid.org/0000-0001-5652-0900

Lidiia Khuda iD https://orcid.org/0000-0002-1098-7537

Olha Kushniryk iD https://orcid.org/0000-0003-1001-6711

Andrzej Kapusta iD https://orcid.org/0000-0001-8979-5468

\section{References}

Aruho C., Walakira J.K., Owori-Wadunde A., Nuwamanya E., Bugenyi F., Sserwadda M., Rutaisire J., Borski R.J. 2020 - Growth and survival of Ripon barbel (Barbus altianalis) larvae and juveniles fed five experimental diets in captivity - Aquac. Rep. 18: 100441.

Becker E.W. 2007 - Micro-algae as a source of protein Biotechnol. Adv. 25: 207-210.

Ben-Amotz A., Polle J.E., Rao D. S. 2009 - The Alga Dunaliella: Biodiversity, Physiology, Genomics and Biotechnology - Enfield, NH: Science Publishers. 188.

Bernaerts M.M., Gheysen L., Foubert I., Hendrickx M.E., Van Loey A.M. 2019 - The potential of microalgae and their biopolymers as structuring ingredients in food: A review - Biotechnol. Adv. 37(8): 107419.

Brett M.T., Müller-Navarra D.C., Ballantyne A.P., Ravet J.L., Goldman C.R. 2006 - Daphnia fatty acid composition reflects that of their diet - Limnol. Oceanogr. 51: 2428-2437.

Brown M.R. 2002 - Nutritional value of microalgae for aquculture - In: Avances en Nutriciòn Acuìcola VI. Memorias del VI Simposium Internacional de Nutriciòn Acuìcola (Eda) L.E. Cruz-Suàrez, D. Ricque-Marie, M. Tapia-Salazar, M.G. Gaxiola-Cortès, N. Simoes, 3 al 6 de Septiembre del 2002, Cancùn, Quintana Roo, Mèxico: 281-292. 
Cheban L., Grynko O. 2017 - Use of Acutodesmus dimorphus (Turpin) tsarenko as a fodder organism for Daphnia growing - Acta Biol. Univ. Daugavp. 17: 141-148.

Cheban L., Malischuk I., Marchenko M. 2015 - Peculiarities of cultivation Desmodedesmus armatus (Chocl.) Hegew. in the wash water from RAS - Arch. Pol. Fish. 23: 155-162.

Cheban L., Grynko O., Dorosh I. 2018 - Co-cultivation of Daphnia magna (Straus) and Desmodesmus armatus (chod.) Hegew. in recirculating aquaculture system wastewater - Fish. Aquat. Life. 26: 57-64.

Conceição L.E., Yúfera M., Makridis P., Morais S., Dinis M.T. 2010 - Live feeds for early stages of fish rearing - Aquac. Res. 41: 613-640.

Duong V.T., Ahmed F., Thomas-Hall S.R., Quigley S., Nowak E., Schenk P.M. 2015 - High protein- and high lipid-producing microalgae from Northern Australia as potential feedstock for animal feed and biodiesel - Front. Bioeng. Biotechnol. 3: 53-61.

Folch J., Lees M., Stanley G.H.S. 1957 - A simple method for the isolation and purification of total lipids from animal tissues - J. Biol. Chem. 226: 497-509.

González López C.V., García M.C.C., Fernández F.G.A., Bustos C.S., Chisti Y., Sevilla J.M.F. 2010. - Protein measurements of microalgal and cyanobacterial biomass Bioresour. Technol. 101: 7587-7591.

Guedes A.C., Amaro H.M., Malcata F.X. 2011 - Microalgae as sources of carotenoids - Mar. Drugs. 9: 625-644.

Hamre K., Yúfera M., Rønnestad I., Boglione C., Conceição L.E., Izquierdo M. 2013 - Fish larval nutrition and feed formulation: knowledge gaps and bottlenecks for advances in larval rearing - Rev. Aquac. 5: S26-S58.

Harel M., Koven W., Lein I., Bar Y., Behrens P., Stubblefield J., Zohar Y., Place A.R. 2002. Advanced DHA, EPA and ArA enrichment materials for marine aquaculture using single cell heterotrophs - Aquaculture 213: 347-362.

Harris R.P., Wiebe P.H., Lenz J., Skjoldal H.R., Huntley M. 2000 - Zooplankton methodology manual - Academic Press, London.

Hosseini Tafreshi A., Shariati M. 2009 - Dunaliella biotechnology: methods and applications - J. Appl. Microbiol. 107: 14-35.

Hu Q., Sommerfeld M., Jarvis E., Ghirardi M., Posewitz M., Seibert M., Darzins A. 2008 - Microalgal triacylglycerols as feedstocks for biofuel production: perspectives and advances - Plant J. 54: 621-639.

Khudyi O., Marchenko M., Cheban L., Khuda L., Kushniryk O., Malishchuk I. 2016 - Recirculating aquaculture systems waste water as a medium for increase of phytoplankton and zooplankton biomass - Int. Lett. Nat. Sci. 54: 1-7.

Kolkovski S. 2001 - Digestive enzymes in fish larvae and juveniles - implications and applications to formulated diets - Aquaculture 200: 181-201.
Kolman R., Khudyi O., Kushniryk O., Khuda L., Prusinska M., Wiszniewski G. 2018 - Influence of temperature and Artemia enriched with $\mathrm{x}-3$ PUFAs on the early ontogenesis of Atlantic sturgeon, Acipenser oxyrinchus Mitchill, 1815 - Aquac. Res. 4: 1740-1751.

Knight J.A., Anderson S., Rawle J.M. 1972 - Chemical basis of the sulfo-phospho-vanillin. Reaction for estimating total serum lipid - Clin. Chem. 18: 199-202.

Kushniryk O., Khudyi O., Khuda L., Kolman R., Marchenko M. 2015 - Cultivating Moina macrocopa Straus in different media using carotenogenic yeast Rhodotorula-Arch. Pol. Fish. 23: 37-42.

Lowry O.H., Rosebrough N.J., Farr A.L., Randall R.J. 1951 Protein measurement with the Folin phenol reagent - J. Biol. Chem. 193: 265-275.

Makridis P, Vadstein O. 1999 - Food size selectivity of Artemia franciscana at three developmental stages - J. Plankton Res. 21: 2191-2201.

Monroig Ó., Navarro J.C., Amat F., Hontoria F. 2007 Enrichment of Artemia nauplii in vitamin A, vitamin C and methionine using liposomes - Aquaculture 269: 504-513.

Nermin A. 2011 - The polyphasic description of a Desmodesmus spp. isolate with the potential of bioactive compounds production. - Biotechnol. Agron. Soc. Environ. 15: 231-238.

Ovie S.I., Egborge A.B.M. 2002 - The effect of different algal densities of Scenedesmus acuminatus on the population growth of Moina micrura Kurz (Crustacea: Anomopoda, Moinidae) - Hydrobiologia 477: 41-45.

Prusińska M., Kushniryk O., Khudyi O., Khuda L., Kolman R. 2015 - Impact of enriching larval brine shrimp (Artemia sp.) with a supplement containing polyunsaturated fatty acids on their growth and mortality - Arch. Pol. Fish. 23: 149-154.

Roe S.H. 1955 - The determination of sugar in blood and spinal fluid with anthrone reagent - J. Biol. Chem. 212: 334-343.

Safi C., Zebib B., Meraha O., Pontaliera P., Vaca-Garcia C. 2014 - Morphology, composition, production, processing and applications of Chlorella vulgaris: A review Renew. Sust. Energ. Rev. 35: 265-278.

Salama E.S., Kim H.C., Abou-Shanab R.I., Ji M.K., Oh Y.K., Kim S.H., B.H. Jeon 2013 - Biomass, lipid content, and fatty acid composition of freshwater Chlamydomonas mexicana and Scenedesmus obliquus grown under salt stress - Bioprocess Biosyst. Eng. 36: 827-833.

Samek D., Mišurcová L., Machů L., Buňka F., Fišera M. 2013 - Influencing of amino acid composition of green freshwater algae and cyanobacterium by methods of cultivation -Turk. J. Biochem. 38: 360-368.

Macías-Sánchez M.D., Serrano C.M., Rodríguez M.R., de la Ossa E.M., Lubián L.M., Montero O. 2008 - Extraction of carotenoids and chlorophyll from microalgae with 
supercritical carbon dioxide and ethanos as cosolvent - J. Sep. Sci. 31: 1352-1362.

Simon M. 2016 - Use of brine shrimp (artemia) in the feeding of sturgeon juveniles (Acipenseridae) (Review) Ribogospod. nauka Ukr. 2 (36): 97-122 (in Ukrainian).

Sorgeloos P., Dhert P. Candreva P. 2001 - Use of the brine shrimp, Artemia spp., in marine fish larviculture Aquaculture 200: 147-159.

Tanaka Y. 1978 - Comparative biochemical studies on carotenoids in aquatic animals - Mem. Fac. Fish. 27: 355-422.

Van der Meeren T., Mangor-Jensen A., Pickova J. 2007 - The effect of green water and light intensity on survival, growth and lipid composition in Atlantic cod (Gadus morhua) during intensive larval rearing - Aquaculture 265: 206-217.

Viciano E., Monroig O., Salvador A., Amat J., Fiszman S., Navarro J.C. 2015 - Enriching Artemia nauplii with a high DHA - containing lipid emulsion: search for an optimal protocol - Aquac. Res. 46: 1066-1077.

Villarruel-López A., Ascencio F., Nuńo K. 2017 - Microalgae, a potential natural functional food source - a review Pol. J. Food Nutr. Sci. 67: 251-263.

Watanabe T., Kitajima C., Fujita S. 1983 - Nutritional values of live organisms used in Japan for mass propagation of fish: a review - Aquaculture 34: 115-143. 